Голуб Н. Д., кандидат сільськогосподарських наук

Полтавська державна аграрна академія

\title{
КОМБІНАЦІЙНА ЗДАТНІСТЬ СВИНЕЙ ВЕЛИКОЇ БІЛОЇ ПОРОДИ ОКРЕМИХ ГЕНЕАЛОГІЧНИХ ЛІНІЙ І РОДИН
}

\section{Рецензент - кандидат сільськогосподарських наук О. О. Васильєва}

\begin{abstract}
Наведена характеристика репродуктивних і відгодівельних ознак окремих ліній кнурів і родин свиноматок й визначена їх комбіначійна здатність за багатоплідністю. Кращі поєднання встановлені між кнурами генеалогічних лінії Громкого і родини Сої, Свата і Тайги, Шалуна і Сої, ВБУП $і$ Чорної птички - 11 поросят і більше. Очінка кнурів і свиноматок за відгодівельними якостями нащадків показала достатньо високі результати. Одержані середньодобові прирости на рівні 614-795 2, вік досягнення живої маси 100 кг-202-178 днів, витрати кормів на 1 кг приросту - 4,21-3,42 к. од.

Крашчии за відгодівельними якостями є кнури генеалогічних ліній Свата, Громкого, Шалуна, Оріона і кнури великої білої породи датського походження.
\end{abstract}

Ключові слова: багатоплідність, жива маса, довжина тулуба, лінії, родини, генеалогія, гетерозис, комбінаційна здатність.

Постановка проблеми. Встановлено, що продуктивність свиней у значній мірі визначається вибором вихідних порід. Без перевірки на поєднаність гарантувати прояв гетерозису неможливо - це характерно як для міжпородної, так і для внутрішньопородної гібридизації.

Комбінаційна здатність $є$ важливою характерною рисою батьківських форм, що зумовлюють їх гетерозис. Тому здатність порід, типів і ліній давати при схрещуванні гібридних нащадків із вищою продуктивністю має важливе значення у процесі добору вихідних порід для гібридизації. Основними критеріями оцінки такої здатності, тобто поєднаності порід та ліній, $є$ рівень загальної (ЗКЗ) і специфічної (СКЗ) комбінаційної здатності [6].

У зв'язку з цим оцінка порід і ліній, які беруть участь у схрещуванні на комбінаційну здатність, заслуговує на увагу, а виявлення кращих поєднань має неабияке практичне значення для підвищення виробництва продукції.

Багаторічний селекційний досвід свиноводів усього світу показав, що справжній і гарантований ефект гетерозису можна отримати лише в результаті схрещування окремо відселекціонованих батьківських і материнських форм, перевірених на поєднуваність, і які мають специфіч- ну комбінаційну здатність. Ефективність селекції у значній мірі залежить від взаємодії генотипів схрещуваних особин.

Отже, проведення досліджень із перевірки комбінаційної здатності створених спеціалізованих типів і порід має справжній науковий і практичний інтерес, оскільки сприяє значному покращанню продуктивності свиней та удосконаленню даних типів і порід.

Аналіз основних досліджень і публікацій, у яких започатковано розв'язання проблеми. У виробництві найбільш простим і доступним способом використання ефекту гетерозису $\epsilon$ промислове схрещування. Проте, як показала практика, в сучасних умовах воно вичерпало свої потенційні можливості. У зв'язку з цим перед вченими постало завдання розробити нові, більш ефективні методи, здатні забезпечити значне підвищення продуктивності свиней і покращання якості одержуваної продукції. Одним із таких методів $є$ гібридизація, здатна гарантувати у помісних тварин стійкість високого ефекту гетерозису, порівняно 3 простим промисловим схрещуванням.

На даному етапі під гібридизацією розуміють не тільки парування тварин різних видів, а й поєднання тварин, спеціалізованих за окремими ознаками батьківських і материнських ліній у межах одної або різних порід.

При поєднанні свиней різних генотипів спостерігається підвищення показників відтворювальної здатності, енергії росту, відгодівельних якостей, збільшення морфофункціональних значень, тобто, збільшення кількості еритроцитів, гемоглобіну, загального білка, діаметра м'язового волокна, покращання показників клітинного та гуморального імунітету тощо [1].

Важливим резервом підвищення продуктивності (на 5-15\%) різних порід заводських типів, ліній і родин в умовах виробництва є раціональне використання методів внутрішньопородного розведення та гібридизації. Ефективним методом підвищення репродуктивних якостей свиноматок $\epsilon$ породнолінійна гібридизація. Багатоплідність маток підвищується на 15,0-17,2 \%, маса поросят при відлученні - на 6,1-9,1% [2]. 
Міжлінійні внутрішньопородні кроси, порівняно 3 лінійним розведенням, сприяють підвищенню продуктивних якостей свиноматок за багатоплідністю на 6-8 \%, молочністю - на $1,1-2,4 \%$, середньою живою масою голови в 2-місячному віці - на 1,2-2,3\%. Живої маси 100 та 120 кг міжлінійні підсвинки досягали, порівняно з лінійними тваринами, на 5,4-7,0 та 7,0-9,0 днів раніше при середньодобових приростах на 28-51 та 28-56 г більше, витрачаючи при цьому на 1 кг приросту на 0,12 0,26 та $0,14-0,32$ корм. одиниці менше.

Найбільший ефект гетерозису отриманий за породно-лінійної гібридизації: багатоплідність маток підвищилася на $15,0-17,2 \%$, молочність на $12,4-17,8 \%$. Живої маси 120 кг гібриди досягали раніше своїх ровесників на 17,9-24,0 днів, середньодобовий приріст збільшився на 92126 г, а витрати кормів зменшилися на 0,57-0,73 корм. одиниці $[4,5]$.

Суттєвим у частці результативної оцінки $\epsilon$ ефект гетерозису, що зумовлений відповідним поєднанням порід, типів, ліній та родин. В останні роки створені нові породи, спеціалізовані лінії й типи, заводські лінії, які в поєднанні забезпечують високий ефект гетерозису $[2,3]$.

Метою роботи $\epsilon$ вивчення комбінаційної здатності в стаді свиней великої білої породи за багатоплідністю, визначення репродуктивних i відгодівельних якостей у розрізі генеалогічних ліній i родин у племзаводі ТОВ «Агрофірма «Низи»»» Сумської області.

Методика досліджень. Генеалогічний аналіз проводили на основі родоводів, записаних у заводських картках кнурів і свиноматок.

Розвиток кнурів вивчали у віці 12 і 24 місяці, а свиноматок - на 5-10-й день після першого опоросу, за живою масою (шляхом зважування до годівлі) й довжиною тулуба (вимірювали мірною стрічкою від потиличного гребня до кореня хвоста). Продуктивність кнурів вивчали за багатоплідністю спарованих ними свиноматок і живою масою 1 поросяти у віці 2 місяці. Продуктивність свиноматок вивчали за багатоплідністю і масою гнізда поросят у віці 2 місяці, кг.

Відгодівельні і м'ясні якості свиней вивчали безпосередньо в господарстві за методикою М. Березовського та I. Хатька.

Результати досліджень. Основне стадо кнурів і свиноматок характеризується хорошим розвитком і продуктивністю. Жива маса кнурівплідників у віці 12 місяців становить 205-220 кг, довжина тулуба - 164-169 см. Дорослі кнуриплідники у віці 24 місяці мають живу масу $306-$ 326 кг, довжина тулуба - 181 сантиметр.

Розвиток свиноматок також на рівні класу еліта. У віці 15-16 місяців жива маса свиноматок становить 188-195 кг, довжина тулуба - 156-157 сантиметрів. Продуктивність свиноматок достатньо висока. Свиноматки по першому опоросу мають багатоплідність (11,5-11,6 поросят), маса гнізда поросят у віці 2 місяці - 185-199 кілограмів. Свиноматки 3 двома i більше опоросами мають багатоплідність (11-11,3 поросят), масу гнізда поросят у два місяці - 185 кілограмів.

Особлива увага надається відбору свиноматок до провідної групи, куди відбирається близько $25 \%$ маток кращих за розвитком і продуктивністю.

Багатоплідність свиноматок провідної групи становить 11,85 поросят, маса гнізда поросят у віці 2 місяці - 189-192 кілограми.

Генеалогічний аналіз основного стада свиней показав, що кнури-плідники відносяться до 12 генеалогічних ліній, свиноматки - до 10 генеалогічних родин.

Основними генеалогічними лініями в стаді $\epsilon$ лінії Громкого, Свата і датського походження. Крім того в стаді працюють кнури-плідники генеалогічних ліній Шалуна, Лафета, Драчуна Йоли, Принца, Некку, Вінцера, а також угорського походження генеалогічні лінії Balle, Donald, Egon, Quinar I Ami.

У процесі удосконалення порід суттєве значення має виявлення найбільш вдалих комбінаційних поєднань кнурів і свиноматок, а також максимальне їх використання як при індивідуальному підборі, так і в межах окремих генеалогічних ліній і родин.

Нами було проаналізовано 992 опороси свиноматок у розрізі генеалогічних ліній і родин. Для аналізу були взяті 5 провідних у стаді генеалогічних ліній Громкого, Свата, Шалуна, лінії кнурів датського й угорського походження $\mathrm{i}$ 5 генеалогічних родин свиноматок - Волшебниці, Чорної птички, Гвоздики, Тайги і Сої.

Результати досліджень наведені в таблиці. Як свідчать дані таблиці, кнури генеалогічної лінії Громкого найкращу комбінаційну здатність за багатоплідністю показали зі свиноматками генеалогічних родин Сої - 11,0 поросят, Волшебниці і Чорної птички - 10,73 і 10,72 голів відповідно.

На рівні 10,3-10,4 голів багатоплідність у поєднанні зі свиноматками генеалогічних родин Гвоздики і Тайги.

Кнури генеалогічної лінії Свата кращу комбінаційну здатність виявили в поєднанні зі свиноматками генеалогічної родини Тайги - 11,0 поросят, Чорної птички - 10,85 голів і Гвоздики 10,8 поросят. Кращі показники багатоплідності у кнурів генеалогічної лінії Шалуна - 10,7 поросят, ВБПД - 10,76 поросят і ВБУП - 10,82 голів. Найвищі результати одержані за поєднання кнурів генеалогічної лінії Шалуна зі свиноматками 
СІЛЬСЬКЕ ГОСПОДАРСТВО. ТВАРИННИЦТВО

Комбінаційна здатність кнурів і свиноматок окремих генеалогічних ліній і родин за багатоплідністю

\begin{tabular}{|c|c|c|c|c|c|c|c|c|c|c|c|c|}
\hline \multirow{3}{*}{$\begin{array}{l}\text { Генеалогі- } \\
\text { чні лінії }\end{array}$} & \multicolumn{10}{|c|}{ Генеалогічні родини } & \multicolumn{2}{|c|}{ Середнє } \\
\hline & \multicolumn{2}{|c|}{ Волшебниці } & \multicolumn{2}{|c|}{ Чорної птички } & \multicolumn{2}{|c|}{ Гвоздики } & \multicolumn{2}{|c|}{ Тайги } & \multicolumn{2}{|c|}{ Coï } & & \multirow{2}{*}{$\mathrm{M} \pm \mathrm{m}$} \\
\hline & $\mathrm{n}$ & $\mathrm{M} \pm \mathrm{m}$ & $\mathrm{n}$ & $\mathrm{M} \pm \mathrm{m}$ & $\mathrm{n}$ & $\mathrm{M} \pm \mathrm{m}$ & $\mathrm{n}$ & $\mathrm{M} \pm \mathrm{m}$ & $\mathrm{n}$ & $\mathrm{M} \pm \mathrm{m}$ & & \\
\hline Громкого & 84 & $\begin{array}{c}10,73 \pm \\
0,03\end{array}$ & 57 & $\begin{array}{c}10,72 \pm \\
0,06\end{array}$ & 25 & $\begin{array}{c}10,4 \pm \\
0,04 \\
\end{array}$ & 22 & $\begin{array}{c}10,3 \pm \\
0,06 \\
\end{array}$ & 32 & $\begin{array}{c}11,0 \pm \\
0,05 \\
\end{array}$ & 246 & $\begin{array}{c}10,6 \pm \\
0,06\end{array}$ \\
\hline Свата & 74 & $\begin{array}{c}10,5 \pm \\
0,06\end{array}$ & 52 & $\begin{array}{c}10,85 \pm \\
0,05\end{array}$ & 9 & $\begin{array}{c}10,8 \pm \\
0,03\end{array}$ & 11 & $\begin{array}{c}11,0 \pm \\
0,07\end{array}$ & 27 & $\begin{array}{c}10,7 \pm \\
0,06\end{array}$ & 189 & $\begin{array}{c}10,6 \pm \\
0,07\end{array}$ \\
\hline Шалуна & 26 & $\begin{array}{c}10,85 \pm \\
0,04\end{array}$ & 27 & $\begin{array}{c}10,65 \pm \\
0,04\end{array}$ & 7 & $\begin{array}{c}10,86 \pm \\
0,07\end{array}$ & 16 & $\begin{array}{c}10,7 \pm \\
0,04\end{array}$ & 14 & $\begin{array}{c}10,93 \pm \\
0,03\end{array}$ & 90 & $\begin{array}{c}10,7 \pm \\
0,04\end{array}$ \\
\hline ВБДП & 11 & $\begin{array}{c}10,76 \pm \\
0,07\end{array}$ & 100 & $\begin{array}{c}10,92 \pm \\
0,07\end{array}$ & 56 & $\begin{array}{c}10,58 \pm \\
0,05\end{array}$ & 22 & $\begin{array}{c}10,8 \pm \\
0,03\end{array}$ & 41 & $\begin{array}{c}10,85 \pm \\
0,04\end{array}$ & 370 & $\begin{array}{c}10,76 \pm \\
0,03\end{array}$ \\
\hline ВБУП & 34 & $\begin{array}{c}10,71 \pm \\
0,04\end{array}$ & 21 & $\begin{array}{c}11,14 \pm \\
0,05\end{array}$ & 9 & $\begin{array}{c}10,56 \pm \\
0,03\end{array}$ & 16 & $\begin{array}{c}10,83 \pm \\
0,01\end{array}$ & 16 & $\begin{array}{c}10,75 \pm \\
0,07\end{array}$ & 97 & $\begin{array}{c}10,02 \pm \\
0,04\end{array}$ \\
\hline
\end{tabular}

генеалогічних родин Сої $(10,93)$, Гвоздики $(10,86)$ і Волшебниці $(10,85)$ поросят. Кнури датського походження кращі показники мають у поєднанні з матками генеалогічних родин Чорної птички, Тайги і Сої - 10,92 - 10,8 голів.

Кнури угорського походження виявили високу комбінаційну здатність зі свиноматками генеалогічних родин Чорної птички - 11,14 і Тайги 10,83 голів. У племзаводі проводилась оцінка кнурів і свиноматок за відгодівельними якостями нащадків. Одержані середньодобові прирости на рівні 614-795 г, вік досягнення живої маси 100 кг - 202-178 днів, витрати кормів на 1 кг приросту - 4,21-3,42 к. од.

Наведені вище дані свідчать, що в стаді $€$ значні перспективи поліпшення відгодівельних якостей свиней шляхом їх оцінки та відбору за вказаними ознаками. Кращими за відгодівельними якостями $є$ кнури генеалогічних ліній Свата, Громкого, Шалуна, Оріона і кнури великої білої породи датського походження. Найкращі результати одержані від кнурів ВБДП. Так, нащадки кнура за номером L05839 показали середньодобові прирости 795 г, вік досягнення живої маси 100

\section{БІБЛІОГРАФІЯ}

1. Березовський Н. Д. Продуктивность свиноматок внутрипородного типа УКБ-1 в сочетании с хряками отцовских форм / Н. Д. Березовский, Ю. С. Ціганчук // Свиноводство. - К. : Урожай, 1987. - Вип. 43. - С. 3-5.

2. Бучко М. А. Економічна ефективність міжлінійної і породно-лінійної гібридизації свиней / М. А. Бучко, В. П. Пундик, О. Ф. Цап // Свинарство. - К. : Урожай, 1991. - Вип. 48. - С. 15-19.

3. Бучко М. А. Породно-лінійна гібридизація свиней на комплексі промислового типу / М. А. Бучко, М. Д. Петрів, О. Ф. Цап // Свинарство. - К. : Урожай, 1992. - Вип. 48. - С. 8-12. кг - 178 днів і витрати кормів на 1 кг приросту 3,42 к. од. Даний кнур має досить високі м'ясні якості: довжина півтуші - 100,7 см, товщина шпику над 6-7-м грудними хребцями 27 мм, площа «м'язового вічка» - 43,4 $\mathrm{cm}^{2}$ і маса окосту - 11,0 кілограмів.

У цілому стадо свиней племзаводу відзначається хорошими м'ясними якостями. Використання в стаді кнурів-плідників великої білої породи естонської, німецької та англійської селекції сприяло формуванню свиней із покращеними м'ясними якостями. Довжина півтуші коливається в межах 100,3-101,7 см, товщина шпику 25,2-31,0 мм, площа «м'язового вічка» 26,6 $43,8 \mathrm{~cm}^{2}$, маса задньої треті півтуші - 10,2-11,0 кілограмів. Дані наведені у таблиці.

Висновки. Таким чином, проведений аналіз показав, що в конкретному стаді існує різниця за продуктивними ознаками в розрізі генеалогічних ліній і родин. Отже, при формуванні генеалогічної структури стада, підбору пар для парування необхідно враховувати комбінаційну здатність кнурів і свиноматок за провідними селекційними ознаками.

4. Голуб Н. Д. Вплив поєднань окремих ліній кнурів і родин свиноматок на їх продуктивність / Н. Д. Голуб // Свинарство. - 1978. - Вип. 29. C. 17-20.

5. Данилов C. Сочетаемость линий и семейств при чистопородном разведении свиней крупной белой породы / С. Данилов, В. Герасимов, Т. Данилова // Свиноводство. - 1997. - №4. - С. 13-18.

6. Лісний В. А. Підвищення ефективності гетерозисної селекції в свинарстві шляхом оцінки комбінаційної здатності порід та типів свиней / В. А. Лісний, I. В. Назаренко // Вісник аграрної науки Причорномор'я. - М., 2002. - Вип. 3. - С. 58-66. 